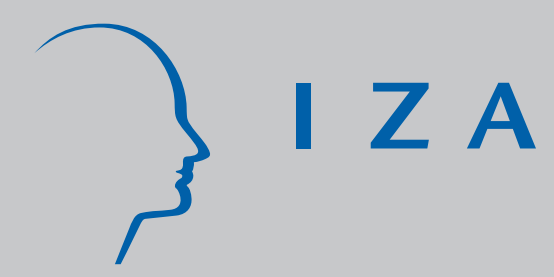

IZA DP No. 353

Flexible Work Systems and the Structure of Wages: Evidence from Matched EmployerEmployee Data

Thomas K. Bauer

Stefan Bender

August 2001 


\title{
Flexible Work Systems and the Structure of Wages: Evidence from Matched Employer-Employee Data
}

\author{
Thomas K. Bauer \\ $I Z A$, Bonn, \\ University of Bonn and CEPR, London \\ Stefan Bender \\ Institut für Arbeitsmarkt- und Berufsforschung (IAB), Nürnberg
}

Discussion Paper No. 353

August 2001

(revised: July 2002)

\author{
IZA \\ P.O. Box 7240 \\ D-53072 Bonn \\ Germany \\ Tel.: +49-228-3894-0 \\ Fax: +49-228-3894-210 \\ Email: iza@iza.org
}

This Discussion Paper is issued within the framework of IZA's research area The Future of Labor. Any opinions expressed here are those of the author(s) and not those of the institute. Research disseminated by IZA may include views on policy, but the institute itself takes no institutional policy positions.

The Institute for the Study of Labor (IZA) in Bonn is a local and virtual international research center and a place of communication between science, politics and business. IZA is an independent, nonprofit limited liability company (Gesellschaft mit beschränkter Haftung) supported by the Deutsche Post AG. The center is associated with the University of Bonn and offers a stimulating research environment through its research networks, research support, and visitors and doctoral programs. IZA engages in (i) original and internationally competitive research in all fields of labor economics, (ii) development of policy concepts, and (iii) dissemination of research results and concepts to the interested public. The current research program deals with (1) mobility and flexibility of labor markets, (2) internationalization of labor markets and European integration, (3) the welfare state and labor markets, (4) labor markets in transition, (5) the future of work, (6) project evaluation and (7) general labor economics.

IZA Discussion Papers often represent preliminary work and are circulated to encourage discussion. Citation of such a paper should account for its provisional character. 
IZA Discussion Paper No. 353

August 2001 (revised: July 2002)

\section{ABSTRACT}

\section{Flexible Work Systems and the Structure of Wages: Evidence from Matched Employer-Employee Data*}

A growing literature is concerned with the effects of flexible workplace systems or High Performance Work Organizations (HPWOs) on wages. This paper makes use of a new employer-employee-linked panel data set for Germany to examine the effects of adopting HPWOs on wages as well as on the wage structure within firms. The empirical results suggest that, depending on the particular practice, flexible workplace systems benefit employees through higher wages. HPWOs further increase within firm wage inequality through a relative increase in the wages at the upper parts of an establishment's wage distribution.

JEL Classification: L2, J3, O3

Keywords: organizational change, wages, linked-employer-employee data set, within-firm inequality

Thomas Bauer

IZA

P.O. Box 7240

53072 Bonn

Germany

Tel.: +49228 3894529

Fax: +492283894510

Email: bauer@iza.org

\footnotetext{
* The authors would like to thank Uwe Bach, Hielke Buddelmeyer, Christian Dustmann, Ira Gang, David Jaeger, Arnd Kölling, Magnus Lofstrom, Christoph M. Schmidt, Steve Trejo, Petra Todd, Melanie Ward, Rainer Winkelmann, and Myeong-Su Yun, the participants of the IZA Research Seminar and the labor seminar at the University of Pompeu Fabra, as well as the participants of the IZA workshop "Organizational Change and Its Implications for the Labor Market", November 16-18, 2000, Bonn, the IZA workshop "Labor Market Analysis Using Matched Employer-Employee Data Sets", November 30 - December 1, 2000, Bonn, the 2001 CEPR/IZA conference "European Summer Symposium in Labour Economics", April 24-28, 2001, Buch am Ammersee, the 15th Annual Conference of the European Society for Population Economics, June 14 - June 16, Athens, the Annual Conference of EALE, September 13-16, 2001, Jyväskyla, the Annual Conference of the Verein für Socialpolitik, September 26-28, 2001, Magdeburg and CAED01, October 8-10, Aarhus, for helpful suggestions on earlier drafts of the paper. Parts of this paper have been written while Stefan Bender was visiting IZA.
} 


\section{Introduction}

Numerous studies have shown that a growing number of firms in developed countries adopt flexible workplace systems in order to cope with increasingly unstable product markets and increasing international competition. These flexible workplace systems, which are often also labeled as innovative work systems or High Performance Work Organizations (HPWOs), are characterized by an increasing importance of team work and job rotation, decentralization of decision making within firms, a reduction in the number of hierarchical levels, the replacement of vertical by horizontal communication channels, the introduction of employee problem-solving groups or quality circles, Total Quality Management (TQM) and a change from task specialization to task diversification. Even though the adoption of these practices varies between countries, industries and firms, the observed reorganization process appears to be of quantitative importance in almost all industrialized economies. Yet, the focus of the debate on flexible work systems has been on the determinants of adopting HPWOs and their effect on organizational performance. More recently, however, an increasing interest in the labor market effects of workplace innovations can be observed.

It has often been argued that HPWOs are "win-win"-systems that benefit both employers and employees. Indeed several theories suggest that HPWOs should lead to higher wages. It is argued, for example, that HPWOs raise skill demands, resulting in higher wages as long as the supply of these skills is scarce. Innovative work systems typically reduce the ease with which firms can monitor their workers which may force employers to pay higher efficiency wages in order to prevent shirking. Finally, empirical studies of the effects of innovative workplace systems on organizational performance have shown that the adoption of these systems leads to increased organizational performance and higher productivity, which in turn creates scope for sharing the resulting gains.

Opponents of the hypothesis that HPWOs create mutual gains argue that it is not clear 
whether employees have enough bargaining power to force employers to share the gains accruing through the introduction of innovative work systems. Empirical evidence suggests that employees prefer to work under HPWOs indicating that they might even be willing to accept lower wages for the opportunity to participate in innovative workplace systems. Several practices, such as team work, job rotation and employee problem solving groups, primarily increase the demand for interpersonal skills. It could be questioned whether these skills are scarce enough for increased demand to yield significant upward wage pressure. Finally, it is not clear whether the skills demanded by HPWOs are general or firm-specific. If they are predominantly firm specific, a higher demand for these skills may not necessarily increase wages. The existing empirical evidence on the wage effects of HPWOs, which is based almost exclusively on data for the US, is relatively scarce and comes to inconclusive results.

The present study uses a unique matched employer-employee panel data set to investigate the wage effects of introducing HPWOs for Germany. The data set provides information on organizational changes which occurred in a representative sample of German firms in the period from 1993 to 1995 together with information on the establishments as well as on the wages, education and other demographic characteristics for all employees in these establishments, who pay social security contributions. Note that during the period covered by our data about $84 \%$ of all employed persons in Germany are required to contribute to the social security system. The paper contributes to the empirical literature on the labor market effects of HPWOs in several respects. First, it complements the existing studies for the US by providing evidence on the wage effects of flexible workplace practices for Germany. Second, most of the existing studies on the wage effects of HPWOs rely on cross-sectional data. These studies suffer from the problem that their results might be biased due to unobserved establishment characteristics which are correlated with both wages and the probability of 
introducing HPWOs. The longitudinal character of our data set enables us to address this problem.

The paper finally contributes to the existing literature by looking on the effects of innovative work practices on the wage structure within firms. Due to insufficient data, this issue has been largely neglected by the literature. Since our data provides wage information for the universe of workers in the establishments covered by the social security system, we are able to analyze the effects of HPWOs on the internal wage structure. The question whether the adoption of HPWOs increases or reduces wage differentials within firms is largely an empirical issue. Recent theoretical contributions, for example, conclude that the adoption of HPWOs leads to a segregation of the labor market with high-skilled workers being predominantly employed in firms using HPWOs as well as low-skilled workers primarily employed in firms organized along the traditional, Tayloristic way. This segregation leads to an increased homogeneity of skills and hence wages within firms. In addition, some central features of HPWOs, such as the reduction of hierarchy levels and transfer of responsibilities to lower hierarchy levels, should result in reduced wage differentials within firms. If employers assign only their most productive workers to high performance practices the adoption of flexible work practices might, however, increase within-firm wage differentials.

\section{Theoretical Background}

Two related issues are at the center of the debate on the labor market effects of HPWOs. The majority of existing studies in this area are concerned with the question whether HPWOs are indeed "win-win"-systems benefiting both employer and employees. Several arguments have been put forward supporting the view that the adoption of innovative workplace systems is associated with wage gains for the employees. The hypothesis that HPWOs create 
mutual gains often rests on the results of empirical studies showing that the adoption of new workplace practices leads to increased organizational performance in terms of higher productivity and quality. ${ }^{1}$ This in turn creates some scope for employers and employees to share the resulting gains.

Another line of argument is based on the nature of the re-organization process as it has been observed in various countries. ${ }^{2}$ HPWOs are typically characterized by the introduction or increasing importance of team work and job rotation, decentralization of decision making within firms, a reduction in the number of hierarchy levels, the replacement of vertical by horizontal communication channels and a change from task specialization to task diversification. These new work practices require high levels of cooperation among workers. In addition, flexible work practices typically reduce the ease with which firms can monitor their workers. Both characteristics of HPWOs - a high commitment of workers to their firm and the latter's reduced opportunity to monitor workers - might result in the need to pay higher efficiency wages. Furthermore, firms that restructure their organization often introduce alternative compensation practices such as bonuses or profit sharing, which might partly be a result of the increased difficulties to monitor the effort of the workers involved in HPWOs. ${ }^{3}$ As a result of these alternative compensation practices one might expect higher wages, if organizational change leads to an increased performance of the firm.

It has further been argued that innovative work systems raise skill demands. Workers employed in firms using flexible workplace practices need to be willing to acquire new skills, to perform multiple tasks and to care about quality and productivity. According to the human capital theory, an increased demand for skills required by HPWOs should increase

\footnotetext{
${ }^{1}$ A survey of the literature is given by Appelbaum and Batt (1994), Capelli and Neumark (2001) and OECD (1999).

${ }^{2}$ Evidence for Europe is provided by the European Foundation $(1997,1998)$ and Osterman $(1994,2000)$ for the US. See Snower (1999) and OECD (1999) for reviews of the literature.

${ }^{3}$ Ostermann (1994), Gittleman et al. (1998) and OECD (1999) provide evidence that flexible workplace practices are positively associated with the use of profit-sharing and pay for skill.
} 
the wage of individuals endowed with these skills. Finally, the theory of compensating wage differentials predicts that the wages of employees involved in flexible workplace practices should increase, if these work place practices reduce the utility of these workers through, for instance, the requirement of a higher effort levels.

There are, however, several arguments that refute the assertion that HPWOs also benefit employees in form of higher wages. First, even if organizational change is associated with productivity gains, workers might not have the bargaining power to force firms to share these gains. Due to differences in the bargaining system between Germany ${ }^{4}$ and the US, this objective seems to be of lower significance for the German labor market. Second, one could be skeptical whether the additional skills required by HPWOs are scarce, since these practices primarily raise the demand for interpersonal, behavioral and communications skills. Even though the empirical evidence on the wage effects of these types of skills is rather limited, existing studies suggest, however, that they produce significant returns (Kuhn and Weinberger 2002). Third, it is possible that workers have a preference for working under HPWOs compared to a traditional organization of the workplace and hence are willing to accept lower wages for the opportunity to participate in these practices. There is indeed some empirical evidence that employees prefer to work under HPWOs (Freeman and Rogers 1999).

A question which has been largely neglected in the literature, is whether the adoption of new workplace system also affects the structure of wages within firms. The implementation of HPWOs might change the internal wage structure of establishments through several channels.

\footnotetext{
${ }^{4}$ The wage setting procedure in Germany is carried out on two different levels and by different actors. In a first step, collective agreements on wages are reached between unions and employer organizations who bargain centralized at the industry and regional level. Pay agreements typically specify the standard minimum wages according to tenure for a range of job categories. Even though there is no minimum wage legislation in Germany, these pay agreements basically provide a lower bound for wages paid in an industry. More important are the wage negotiations which take place at the firm level between the works council, which exists in practically all larger firms and are dominated by the trade unions, and the individual employer. At this level, the parties usually bargain about payment above the tariff norm, either through a higher wage or through non-standard forms of compensation. As a consequence of these firm-level agreements, actual wages in Germany often exceed the collective minimum wages.
} 
First, it has often been hypothesized that flexible work practices are "skill-biased" and hence would increase earnings inequality within firms (Bresnahan et al. 1999, Capelli 1996, Caroli and van Reenen 2001, Egger and Grossmann 2000, Lindbeck and Snower 1996, 2000). The basic assumption behind this hypothesis is that skilled workers have a relative advantage in multi-tasking and a greater ability to acquire new skills. Hence, if HPWOs result in increased firm performance, and if the resulting gains are shared between the firm and its workers, these gains would accrue mainly to skilled workers.

Several theoretical models connect increasing inequality with an increase in skill segregation arising through organizational change (Acemoglu 1999, Kremer and Maskin 1996, and Thesmar and Thoenig 2000). The main idea behind these models is that an increasing supply of skilled labor induces firms to change their organizational structure which in turn leads to a greater homogeneity of the skill structure within firms. The economy moves from an equilibrium where firms employ both skilled and unskilled labor, towards a segregated equilibrium, where skilled workers are predominantly employed in firms using HPWOs and unskilled workers in firms that rely on traditional work organizations. If firms that use HPWOs are more productive than firms relying on traditional workplace systems, this segregation of labor markets by skill groups might provide an additional explanation for rising inequality across firms. The labor market segregation, however, also leads to an increased homogeneity of skills and hence wages within firms.

Several additional arguments suggest that HPWOs reduce within-firm inequality. First, empirical analyses of firms' wage policy suggest that wage dispersion within firms is positively correlated with the number of hierarchy levels in a firm. ${ }^{5}$ Therefore, main characteristics of HPWOs such as the reduction of hierarchy levels and transfer of responsibilities to lower hierarchy levels are expected to reduce wage differentials within firms. Furthermore, practices

\footnotetext{
${ }^{5}$ See, for example, Baker et al. (1994).
} 
such as team work and job rotation should also make wages within firms more equal since they reduce the ability to pay according to individual productivity. Finally, to the extent that several practices predominantly involve production workers, such as TQM, job rotation and team work, one might expect a reduction of pay inequality within firms because they raise the productivity of production workers more than they raise those of supervisors and high-skilled workers. It is possible, however, that employers assign only their most productive workers to high performance practices. In this case, the adoption of flexible work practices might also result in increased within-firm wage differentials.

To summarize, theoretical considerations provide only limited guidance as to whether HPWOs result in higher wages for employees nor whether these practices increase or decrease wage differentials within firms.

\section{Previous Research}

Empirical studies on the labor market effects of organizational change are relatively rare if compared to the vast literature on the determinants and productivity effects of HPWOs. Furthermore, because of significant differences in their research design it is not surprising that existing studies, which are based almost exclusively on data for the US, obtain different results. First, there is no consensus on the definition of HPWOs, since a broad set of practices is subsumed under this term ${ }^{6}$. Many studies use the number of flexible workplace practices in a firm, an indicator variable indicating whether the firm introduced any practice, or use various methods to derive an index indicating the use of innovative human resource practices in a firm. Second, the studies differ in whether they use individual or establishment data. Most studies are based on establishment data. Among those, only few studies employ

\footnotetext{
${ }^{6} \mathrm{~A}$ discussion on the measurement of HPWOs is given by Appelbaum et al. (2000), Ichniowski et al. (1997), OECD (1999), and Ostermann (1994).
} 
representative samples of all establishments; most are based on establishment samples from specific industries and therefore suffer from the problem that their results could not be generalized. Only a minority of the existing studies investigate the wage effects of HPWOs using individual data (Bailey et al. 2001, Handel and Gittleman 1999, Appelbaum et al. 2000).

The existing empirical literature could further be separated into those relying on crosssection data and those who are able to use panel data. Most studies using cross-section data on establishments or individuals conclude that firms that rely on HPWOs pay significant higher wages. Capelli (1996) uses the Educational Quality of the Workforce National Employers Survey (EQW), a representative sample of establishments in the US, to analyze the effect of Total Quality Management (TQM) and self-managed teams on earnings. He finds that TQM and self-managed teams have a positive effect on the wages of production workers. The wages of supervisors are positively affected by the presence of self-managed teams only. The results of Capelli (1996) further indicate that TQM reduces the wage differential between production workers and supervisors, suggesting that HPWOs lead to a more homogeneous pay structure within firms.

The results of Capelli (1996) have been confirmed by several studies that use cross-section data of establishments and individuals in specific industries. Based on a sample of 303 U.S. bank branches, Hunter and Lafkas (1998), for example, find that "high-involvement" practices, measured as an index of the authority to perform various tasks and the participation of a branch in a Quality Circle, increase wages. Based on a representative survey of 354 service and sales centers in the telecommunication industry, Batt (2001) finds that wages are higher in establishments that provide their workers with higher discretion and offer more full-time employment. However, she could not find significant wage effects of problem solving groups and self-directed teams. Bailey et al. (2001) use survey data on over 4,000 employees in 45 
establishments in the apparel, steel and medical electronic industry collected between 1995 and 1997 to investigate the earnings effects of different forms of HPWOs. Their results indicate that employees in establishments that use high-performance work practices earn more than employees in establishments with a traditional work organization.

Osterman (2000) as well as Caroli and van Reenen (2001) investigate the effects of adopting HPWOs on subsequent wage growth. Osterman (2000) uses a representative sample of US establishments collected in 1992 and 1997 to investigate the effects of HPWOs used by firms in 1992 on real wage growth in 1996. His results indicate that the adoption of HPWOs has no or even negative effects on workers compensation. He further shows that the introduction of HPWOs lead to a reduction in the employment of managers and contingent workers. Caroli and van Reenen (2001), which is to our knowledge the only relevant paper which uses non-US data, use representative panel data of British and French establishments. Their results show that in both countries past organizational change has negative effects on the wage bill and employment shares of unskilled manual workers, indicating that the effects of organizational change in these countries is skill-biased in the sense that it reduces the demand for unskilled workers. Even though the authors do not address the question of within-firm inequality directly, their results suggest that the adoption of HPWOs increase wage differentials within firms by reducing the relative wage of unskilled workers.

Estimates based on cross-sectional data might be biased because of unobserved establishment or individual fixed effects which are correlated with both wages and the probability of organizational change or the probability to be involved in these practices, respectively. This issue has been addressed by Black and Lynch (2000), who use the Educational Quality of the Workforce National Employers Survey (EQW), a panel data set of US establishments for the years 1993 and 1996. Using only the cross-section for 1996, they find that re-engineering a workplace to incorporate more high performance practices, the proportion 
of workers meeting regularly in groups and the proportion of workers in self-managed teams do not significantly affect average establishment wages. After removing establishment fixed effects by taking first differences, however, the coefficients on the dummy variable indicating that a firm introduced high performance practices becomes significant positive. Black and Lynch (2000) further investigate the effects of flexible workplace practices on wages in different occupational groups (managers, supervisors, technical workers, production workers and clerical workers), which allows some statements concerning the question whether the effects of HPWOs are skill-biased. Different from Caroli and van Reenen (2001) they do not find systematic patterns of the effects of HPWOs which would indicate that these practices are skill-biased.

\section{Data Description}

The present paper uses a representative German employer-employee linked panel data set to analyze the wage effects of adopting flexible workplace practices. This data set has been constructed through the combination of two separate data sets, linkage being facilitated through a unique firm identification number. The first data set, the IAB-establishment panel, is an annual survey of West-German establishments administered since $1993 .^{7}$ The data set is a representative sample of German establishments employing at least one employee who pays social security contributions. It should be noted at this point that during our sample period about $84 \%$ of all employed persons in Germany are covered by the social security system. The survey was administered through personal interviews and provides general information on the establishment, such as, for example, investment, revenues, the size and composition of their work force, worker turnover, salaries and wages, and changes in the organization of

\footnotetext{
${ }^{7}$ Detailed information on the IAB-establishment panel is given by Bellmann et al. (1994), Bellmann (1997) and Kölling (2000).
} 
workplaces.

The second data set, the so-called Employment Statistics Register, is an administrative panel data-set of all employees in Germany paying social security contributions. ${ }^{8}$ The data set is based on the integrated notifying procedure for health insurance, statutory pension scheme and unemployment insurance, which was introduced in 1973 . To comply with legal requirements, employers must provide information to the social security agencies for all employees required to pay social security contributions. These notifications are required for the beginning and ending of any employment relationship. In addition, employers are obliged to provide an annual report for each employee covered by social insurance who is employed on the $31^{\text {st }}$ December of each year. This report includes information on gender, year of birth, nationality, marital status, number of children, occupation, and qualification of the employee as well as the industry and the size of the employer.

Both data sets contain a unique firm identification number, which allows us to match information on all employees obliged to pay social security with the establishments in the IAB-establishment panel. ${ }^{9}$ Matching of the two data sets occurred in two steps. In a first step, we exclude firms in the agricultural and mining sector, non-profit firms as well as all firms with missing values for the variables used in the empirical analysis leaving 2,488 of the original 3,261 observations for the year 1993, 2,875 of the initial 3,472 observations for 1995, and 2,247 out of 3,297 observations for 1997. In order to have enough variation in the wage distribution of an establishment and to facilitate comparability with existing studies for the US, we further restrict our analysis to establishments with at least 20 employees. This reduces our sample to 1,722 observations for 1993, 1,935 observations for 1995, and 1,460 for 1997. Finally, we restrict our sample to establishments who participated in the IAB-establishment

\footnotetext{
${ }^{8}$ Information on the Employment Statistics Register is given by Bender et al. (1996, 2000).

${ }^{9}$ Access to this data set will soon be available through the IAB-Establishment Panel Data Service (IPDS). More detailed information on data access may be obtained through the authors.
} 
panel in 1993 and 1995, leaving 1,637 observations for each year. Considering in addition only those establishments who also participated in 1997 reduces our sample further to 1,175 observations.

In a second step, we use the Employment Statistics Register to obtain work history information for all full-time employed persons who worked for at least one day per year within one of the selected establishments. The individual information has been extracted for every $30^{\text {th }}$ of June, the day of reference for the IAB-establishment panel. We exclude from our individual sample apprentices, trainees, persons who are temporarily out of the labor force because of, e.g., child bearing or military service, and individuals older than 65 from our individual sample. Using the firm identifier, the two data sets were matched creating a linked employer-employee data set that provides detailed information on the characteristics of all employees in a particular establishment who are covered by the social security system. We merged information on 1,253,082 employees from the Employment Statistics Register to our sample from the IAB-establishment panel for 1993, 1,171,205 employees for 1995, and 835,675 employees for 1997.

In 1995, the IAB-establishment panel contained several questions on changes in the organization of work. In this year, the establishments were asked the following question: "Over the last two years, have there been any of the following organizational changes in your establishment?". Among the possible answers, we use the following to define indicators of organizational change: "Reduction of the number of hierarchy levels", "Passing on of responsibilities to subordinates", and "Introduction of team work or self-responsible working groups". A major weakness of the information on the use of HPWOs provided in the IABestablishment panel is that we only know whether a firm introduced one or several of the new forms of flexible work practices. Unfortunately, the data set gives no information on the number of employees which are covered by these changes. 
Using the available information, we created dummy variables indicating whether there has been one of the above organizational changes between 1993 and 1995. The work of Milgrom and Roberts $(1990,1995)$ indicates that only the introduction of a cluster of new practices allows firms to reach a new optimal organization that leads to a higher performance. If practices are introduced in clusters the above indicators of organizational change should be highly correlated with each other, which could make it hard to identify the separate effects of these indicators in an empirical investigation of the effects of organizational changes on labor market outcomes. We therefore constructed an index indicating the degree of decentralization applying a principal component analysis to the three dummy-variables described above. ${ }^{10}$

Table 1 shows some descriptive statistics on the incidence of organizational change in our sample. Between 1993 and 1995, 43\% of the establishment had introduced none of the flexible work practices we consider, $26 \%$ at least one, and around $19 \%$ two. More than $12 \%$ had introduced all three of them. On average, the firms in our sample initiated one of the three different practices. With respect to the different forms of organizational innovation it appears that most of the establishments transferred responsibilities to lower hierarchy levels (43\%). Around $28 \%$ of the establishments reduced the number of hierarchy levels and about $31 \%$ introduced self-managed teams. Table 1 further shows that the adoption of HPWOs is relatively more common in the manufacturing sector, which is in line with the experience in other countries (OECD 1999).

\section{Econometric Strategy}

To examine the impact of new workplace practices on wages and the internal wage struc-

\footnotetext{
${ }^{10}$ The first principal component accounted for $56.9 \%$ of the variance and had an eigenvalue of 1.706 . The second and third principal component had eigenvalues below 1, supporting the aggregation of the information on organizational change to one common factor. The scoring coefficients used for the calculation of the decentralization index are 0.440 for the reduction of hierarchy levels, 0.463 for the delegation of responsibilities, and 0.422 for the introduction of team work.
} 
ture in an establishment, we estimate equations of the form

$$
Y_{i t}=X_{i t} \beta+Z_{i} \gamma+\epsilon_{i t}
$$

where $X_{i t}$ is a vector of the characteristics of an establishment in the years $\mathrm{t}=1995,1997$; the vector $Z_{i}$ consists of the variables describing the introduction of flexible workplace practices at establishment $i$ between 1993 and 1995, which have been described above; and $\epsilon_{i t}$ is a standard error term.

As dependent variables, $Y_{i t}$, we consider the mean log real daily wage as well as the log real daily wages in the $20^{t h}$, the $50^{t h}$, and the $80^{t h}$ percentile of the wage distribution in an establishment $i$ in 1995 and 1997, respectively. To investigate the effects of organizational and technological change on the dispersion of wages within establishments more directly we further use the wage differentials between the $80^{t h}$ and $20^{t h}$, the $80^{\text {th }}$ and the $50^{\text {th }}$, and the $50^{\text {th }}$ and $20^{\text {th }}$ percentiles as dependent variables. These variables have been constructed using information on the gross annual income of employees in the Employment Statistics Register. Note, however, that the income information in the Employment Statistics Register is censored from above by the upper limit of the contribution assessment ceiling for social insurance. This upper limit was a daily wage of $236 \mathrm{DM}$ in 1993, $256 \mathrm{DM}$ in 1995, and 269 DM in 1997. In our sample about $10 \%$ of the individuals had censored wages. These individuals are relatively high-skilled; i.e., on average $22 \%$ of engineers and technicians, $13 \%$ of skilled white-collar workers, and $50 \%$ of professionals and managers have censored wage information. The censoring of wages should bias the estimated coefficients on our variables indicating the use of flexible workplace systems towards zero, particularly so for high-skilled workers. To circumvent this bias, we estimated separate Tobit models with the log of real daily wages as dependent variable for the three years for all individuals in our sample. ${ }^{11}$

\footnotetext{
${ }^{11}$ As control variables we included four dummies characterizing the education of an individual, a foreigner dummy, a cubic function of age, three dummy variables indicating the occupational status, a female dummy, a dummy that takes the value 1 if no children are present, an interaction variable between the female dummy
} 
The mean daily wage as well as the wages at different points in the wage distribution of an establishment are then calculated using the predicted wages resulting from these estimations for those individuals above the upper limit of the contribution assessment and the actual wages for all other individuals.

The vector $X_{i}$ includes the log of total employment, five variables indicating the employment share of different skill groups, the employment share of female employees, married employees, and foreigners, the mean age of the employees, a dummy variable indicating whether an establishment is a single firm or part of a multi-establishment firm, and a dummy variable indicating whether a works council is present. We further consider two dummy variables indicating whether the revenues of an establishment increased or decreased during the last year. Establishments reporting stable revenues form the reference group. Establishments have also been asked to rank the technological standard of their production technology relative to other establishments in the sector on a scale from 1 to 5 , where 1 indicates that the machines used by the establishments are obsolete and 5 indicates that the machines are state-of-the-art. We used this information to create a variable indicating the age of the capital used by an establishment.

Many empirical studies on the determinants of rising inequality use information on the proportion of workers using personal-computers or micro-electronic technologies. Unfortunately, the IAB-establishment panel does not provide similar information. Between 1993 and 1995, however, the IAB-establishment panel does contain detailed information on the type of investments in the last year. We use this information to define two dummy variables indicating a technological change between 1993 and 1995. The first variable takes the value of 1 if an establishment reported investments in communication and information technologies in 1993 or 1994, and 0 otherwise. The second variable takes the value 1 if an es-

and the dummy for no children, a dummy variable indicating marital status and 85 occupation dummies. The estimation results are available on request. 
tablishment indicated that these investments in IT have been the single biggest investment, and 0 otherwise. Finally, all cross-sectional estimates included seven industry dummies and nine regional dummies. The definitions and descriptive statistics of all variables used in the empirical analysis are provided in Appendix-Table 1.

Two potential problems occur when estimating equation (1). First, even though our data set allows us to control for many characteristics of an establishment and the structure of its workforce, cross-section estimates of $\gamma$ based on equation (1) might still suffer from omitted variable bias due to unobserved establishment characteristics. To circumvent this problem, we eliminate all observed and unobserved time invariant establishment fixed-effects by taking first differences between 1995 and 1993, and 1997 and 1993, respectively, where 1993 constitutes the year before we observe potential changes in the organization of work. Hence, we estimate equations of the form

$$
\Delta Y_{i t}=\Delta X_{i t} \beta+Z_{i} \gamma+\Delta \epsilon_{i t}
$$

where $\Delta$ indicates the difference operator.

Second, since our variables on organizational change are based on retrospective questions, these variables might suffer from measurement error, leading to biased estimates of $\gamma$. One of the most serious problems with this kind of retrospective data is "forward telescoping", where respondents report events that occurred outside of the time period under consideration, resulting in over-reporting. Note, however, that the retrospective questions on organizational change in the IAB-establishment panel followed a two-step bounded recall procedure. The establishment have not only been asked about organizational changes between 1993 and 1995, but also on organizational changes before 1993, i.e. directly following the question on organizational change in the last two years described above, the interviewer asked "Did your firm introduce any of these changes before 1993?". Several empirical studies have shown that such a two-step bounding procedure can effectively reduce over-reporting 
in retrospective questions. ${ }^{12}$ Unfortunately, there is no suitable alternative data set available that would allow us to assess the possible extent of telescoping in our sample. To our knowledge, only the EPOC-Survey, which has been used by OECD (1999), provides information on the adoption of HPWOs in Germany. However, the EPOC-Survey covers a slightly different time period and contains slightly different questions on organizational change than the IAB-establishment panel. Furthermore, similar to our analysis, the information in the EPOC-Survey also relies on retrospective questions. Different to our data set, however, the EPOC questionnaire does not rely on a two-step bounding procedure. Therefore, if anything, the problem of forward telescoping could be expected to be a relatively bigger problem in the EPOC-Survey if compared to the information used in this analysis. Hence, even though we are not able to exclude the possibility that measurement error might bias our results, empirical studies on the problem of telescoping indicate that this potential bias is effectively reduced by the structure of the questionnaire.

\section{Estimation Results}

The results of estimating equations (1) and (2) including all three dummy variables on organizational change jointly are presented in Table 2. Columns labeled (1) show the crosssectional estimates for 1995 whereas columns labeled (2) the respective first-difference estimates. Note that while the dependent variables and all control variables are differenced, the variables indicating organizational change are effectively not. All equations are estimated using Ordinary Least Squares.

Focusing first on the cross-sectional estimates, the results show that lowering the number of hierarchy levels between 1993 and 1995 affects wages in 1995 positively at all percentiles except the $80^{t h}$. The point estimates indicate that mean wages in 1995 are about $1.3 \%$ higher

\footnotetext{
${ }^{12}$ See, for example, Loftus et al. 1990, Sudman et al. 1984, and Brennan et al. 1996.
} 
in establishments that flattened their management structure in the previous two years. This effect is somewhat higher at the $20^{\text {th }}$ percentile, even though it appears not to be statistically significant different from the effect at the $50^{\text {th }}$ percentile. Increasing employee involvement in decision-making through the transfer of responsibilities to lower hierarchy levels does not affect wages throughout the wage distribution of an establishment. The introduction of selfmanaged teams has effects which are very similar to those of a reduction of the number of hierarchy levels in that they increase wages at all percentiles but the $80^{\text {th }}$.

The estimated effects of organizational change on wages become smaller and are in most cases less precise when using first-differences. The effect of a reduction in the number of hierarchy levels stays significantly positive for the mean wage and the wage at the $20^{\text {th }}$ and $50^{\text {th }}$ percentile; the effect on the wages at the $80^{\text {th }}$ percentile becomes significantly positive. The effect at the $80^{\text {th }}$ percentile is, however, lower than at the other parts of the wage distribution. In contrast to the cross-sectional estimates, the transfer of responsibilities becomes statistically significant at a $5 \%$-level for the $50^{\text {th }}$ percentile, whereas the effect of introducing self-responsible teams does not have any significant wage effects any more. Overall, the changes in the estimates when using first-differences are consistent with unobservable establishment fixed effects that are positively related to wages and the probability of adopting flexible workplace practices.

The other control variables show the expected effects. In the cross-sectional estimates, larger firms pay significantly higher wages. When using first-differences, however, the effect of firm size on wages becomes negative. Wages are increasing with the share of skilled workers, the share of married employees, the share of exports on total revenues and, at least in the cross-sectional estimates, when a works council is present. The share of females, the share of foreigners, and decreasing revenues in the previous year affect wages negatively. Of particular interest are the estimated wage effects of a technological change between 1993 and 
1995. In the cross-sectional estimates, investments in IT have only statistically significant positive effects on wages at the $80^{\text {th }}$ percentile, indicating that technological change is skill biased. When using first differences, however, the positive wage effects of investments in IT at the upper part of the wage distribution disappear, whereas mean wages and wages at the $20^{\text {th }}$ percentile are affected positively.

\section{Robustness of the Results}

The estimates of the effects of organizational change on wages reported in Table 2 might suffer from collinearity problems if establishments tend to adopt workplace practices in systems. Therefore, Panel A of Table 3 reports results for the indicators of organizational change when the three workplace practices enter separately. ${ }^{13}$ Note that each reported coefficient in Table 3 refers to a separate regression. Basically the results when using each HPWO practice separately reinforce the earlier results. A reduction in the number of hierarchy levels have positive effects on wages at all points in the wage distribution, whereas the transfer of responsibilities to lower hierarchy level does not have significant effects. The only remarkable difference to the results reported in Table 2 is that the introduction of self-managed teams has significant positive wage effects at the $80^{\text {th }}$ percentiles even when unobserved establishment fixed-effects are taken into account.

Panel B of Table 3 shows the estimation results, when we use the index of decentralization obtained through principal component analysis instead of the dummy variable for single practices. Recall that this index is increasing with an increasing decentralization between 1993 and 1995. Based on the cross-sectional results, wages in 1995 are significantly increasing with the degree of decentralization that occurred between 1993 and 1995. Only wages at the $80^{\text {th }}$ percentile are not significantly affected by the index. Similar to the earlier results,

\footnotetext{
${ }^{13}$ The full set of estimation results is available on request.
} 
the point estimates become smaller when using first-differences. Furthermore, the effect of the index becomes statistically insignificant for wages at the $20^{\text {th }}$ percentile and statistically significant at the $80^{\text {th }}$ percentile. Overall, the estimates reported in Panel B of Table 3 show that there are significant positive wage effects if an establishment introduces a combination of workplace practices. The results further suggest that these effects are higher at the upper levels of the wage distribution in an establishment.

One might argue that in 1995 not enough time elapsed for organizational changes between 1993 and 1995 to show significant wage effects. The adoption of new workplace practices require a period of adjustment. Workers need to accumulate the necessary skills to work properly in the new environment and need to get used to the new practices. Therefore, it might require some time before organizational change leads to improvements in the performance of organizations and, hence, to wage gains for the employees. To investigate this issue we estimated equations (1) and (2) using cross-section data for 1997 and first-differences between 1997 and 1993.

The results of these estimations for the variables of main interest are shown in Table $4 .{ }^{14}$ Panel A of Table 4 reports the results when all indicators for organizational change between 1993 and 1995 enter jointly, Panel B the results when these indicators enter separately, and Panel $\mathrm{C}$ the results for the index of decentralization. Compared to Tables 2 and 3, the point estimates of the effect of organizational change on wages are somewhat higher when using the 1997 data, indicating that some adjustment period is necessary for the adoption of HPWOs to result in wage gains for the employees. With regard to the effects of the different practices, only few differences to the earlier results appear. Considering the first-difference estimates in Panel A of Table 4 shows, for example, that a reduction of hierarchy levels in the period from 1993 to 1995 leads to significant higher wages in 1997 at the upper levels of the wage

\footnotetext{
${ }^{14}$ The full set of estimation results is available on request.
} 
distribution of an establishment. Wages at the $20^{t h}$ percentile, however, are not significantly affected by a reduction in the number of hierarchy levels. A transfer of responsibilities to lower hierarchy levels and the introduction of self-managed teams have no significant wage effects at all.

These conclusions are basically confirmed by the alternative specifications shown in Panel B and C of Table 4. Similar to the results for 1995, the adoption of self-managed teams has significant positive wage effects, in particular for wages at the upper part of the internal wage distribution. In contrast to the results for 1995, however, wages in 1997 are significantly affected by investments in IT both in the cross-sectional estimates and, with the exception of wages at the $80^{\text {th }}$ percentile, the first-difference estimates. Similar to the results for organizational changes, these results indicate that a technological change also needs some time before benefiting employees in form of higher wages.

The bottom line from these estimation results is that, depending on the particular practice, employees benefit from the adoption of HPWOs. In addition, it seems that these gains accrue primarily to employees at the upper parts of an establishments' wage distribution. Overall, however, these wage gains are estimated to be relatively small. A reduction of hierarchy levels, for example, leads to higher wages for employees. As one would expect, flattening an establishments' organization mainly benefits workers in the middle of the wage distribution. However, also workers at the upper part of the wage distribution gain from a reduction of hierarchy levels. Presumably, this effect appears because this change reallocates tasks from supervisors to lower hierarchies, which in turn raises the productivity of employees at the upper levels of the hierarchy. Effects similar to those of a flattening of the hierarchy structure can be observed for the adoption of self-managed teams. Similar to Capelli (1996), we find that a higher involvement of employees through a transfer of responsibilities does not create wage gains for employees. 


\section{Internal Wage Structure}

Tables 5 and 6 report the results for the variables of interest obtained by estimating equations (1) and (2) using the wage differentials between the $80^{\text {th }}$ and $20^{\text {th }}$, the $80^{\text {th }}$ and the $50^{\text {th }}$, and the $50^{\text {th }}$ and $20^{\text {th }}$ percentiles as dependent variables for the 1995 and 1997 data, respectively. ${ }^{15}$ Using the 1995 data and considering only the first-difference estimates, the introduction of self-managed team significantly increases the differential between the $80^{\text {th }}$ and $20^{t h}$ and the $50^{\text {th }}$ and $20^{\text {th }}$ percentiles. This result is not affected by the specification of the model, i.e., whether the indicators for organizational change enter jointly or separately, and basically does also hold when using data for 1997. A transfer of responsibilities to lower hierarchy levels further seems to increase the wage differential between the $80^{\text {th }}$ and $50^{\text {th }}$ percentiles, whereas a reduction of the number of hierarchy levels has the opposite effects, even though the latter is only statistically significant at a $10 \%$-level. Note, however, that these effects are not robust towards changes in the specification and do not persist when using the 1997 data. The index of decentralization does not have any significant effect on the internal wage distribution when using the 1995 data. The results in Table 6, however, indicate that the adoption of a system of workplace practices increase internal wage inequality in the long-run.

The cross-sectional results reported in Panel A of Table 5 show that investments in IT between 1993 and 1995 seem to strongly increase wage inequality within establishments in particular through a rise in the relative wage at the $80^{t h}$ percentile. These effects disappear, however, as soon as unobserved establishment fixed effects are taken into account by firstdifferencing the data. Note finally, that investments in IT between 1993 and 1995 do not show any statistically significant effects when using the 1997 data.

\footnotetext{
${ }^{15}$ Appendix-Table 2 reports the full set of estimation results using the 1995 data. Results for the 1997 data are available on request.
} 


\section{Summary and Conclusions}

A growing theoretical and empirical literature is concerned with the effects of flexible workplace systems or High Performance Work Organizations (HPWOs) on wages. These flexible workplace systems are characterized by the introduction or increasing importance of self-managed teams, the reduction of the number of hierarchy levels, a decentralization of decision-making within firms, and the replacement of vertical by horizontal communication

channels. The existing theoretical literature provides only limited guidance whether the adoption of HPWOs creates mutual gains, i.e., increases both the performance of an establishment and the wage of its employees. From a theoretical point of view it is unclear how the introduction of flexible workplace practices increases or decreases wage differentials within firms.

This paper makes use of a new employer-employee-linked data set for Germany to examine the effect of flexible workplace systems on the wage structure across and within firms. The panel structure of the data set allows us to avoid problems such as unobserved heterogeneity, which are inherent in most existing empirical studies on this issue. Our estimation results indicate that the adoption of some flexible workplace practices are associated with wage gains for employees. In particular, the flattening of the hierarchy structure of an establishment and the introduction of self-managed teams affect the wages of employees positively, whereas the transfer of responsibilities to employees at the lower hierarchy levels does not have significant wage effects. We find some indication that the adoption of HPWOs, in particular the introduction of self-managed teams, increase wage inequality within firms through a relative increase in the wages at the upper parts of an establishments' wage distribution. Overall, however, these wage effects are estimated to be relatively small. It is noteworthy, 
that a technological change, measured as investments in IT, has, if any, only long-run effects on wages. 


\section{References}

Acemoglu, Daron (1999): "Changes in Unemployment and Wage Inequality: An Alternative Theory and Some Evidence," American Economic Review, 89, 1259-1278.

Appelbaum, Eileen, Thomas Bailey, Peter Berg, and Arne Kalleberg (2000): Manufacturing Advantage: Why High Performance Work Systems Pay Off. Ithaca, N.Y.: ILR Press.

Bailey, Thomas, Peter Berg and Carola Sandy (2001): "The Effect of High- Performance Work Practices on Employee Earnings in the Steel, Apparel, and Medical Electronics and Imaging Industries," Industrial and Labor Relations Review, 54 (2A), 525-543.

Baker, George, Michael Gibbs and Bengt Holmstrom (1994): "The Internal Economics of the Firm: Evidence from Personnel Data," Quarterly Journal of Economics, 109 (November), 881-919.

Batt, Rosemary (2001): "Explaining Wage Inequality in Telecommunications Services: Customer Segmentation, Human Resource Practices, and Union Decline," Industrial and Labor Relations Review, 54 (2A), 425-449.

Bellmann, Lutz (1997b): "The IAB-Establishment Panel with an Exemplary Analysis of Employment Expectations," IAB-Topics No. 20, IAB, Nürnberg.

Bellmann, Lutz, Susanne Kohaut, and J. Kühl (1994): "Enterprise Panels and the Labour Market: Using Enterprise Panels to Meet the Needs of the White Paper," in: E. Ojo (ed.), Enterprise Panels and the European Commission's White Paper. Luxembourg: Eurostat, 57-74.

Bender, Stefan, Anette Haas and Christoph Klose (2000): "IAB Employment Subsample 1975-1995. Opportunities for Analysis Provided by the Anonymised Subsample," IZA Discussion Paper No. 117, IZA, Bonn.

Bender, Stefan, Jürgen Hilzendegen, Götz Rohwer, and Helmut Rudolf (1996): "Die IABBeschäftigtenstichprobe 1975-1990. Eine praktische Einführung," Beiträge zur Arbeitsmarkt- und Berufsforschung, 197.

Black, Sandra E., and Lisa M. Lynch (2000): "What's Driving the New Economy: The Benefits of Workplace Innovation," NBER Working Paper No. 7479, NBER, Cambridge.

Brennan, Mike, Joanna Chan, Dean Hini and Don Esslemont (1996): "Improving the Accuracy of Recall Data: A Test of Two Procedures," Marketing Bulletin, Vol. 7, 20-29.

Bresnahan, Timothy F., Erik Brynjolfsson, and Lorin M. Hitt (1999): "Information Technology, Workplace Organization and the Demand for Skilled Labor: Firm-level Evidence," NBER Working Paper No. 7136, NBER, Cambridge.

Capelli, Peter (1996): "Technology and Skill Requirements: Implications for Establishment Wage Structures," New England Economic Review, May/June, 138-154.

Capelli, Peter and David Neumark (2001): "Do "High-Perfromance" Work Practices Improve Establishment-Level Outcomes?," Industrial and Labor Relations Review, Vol. 54, No. 4 (July), 737-775. 
Caroli, Eve, and John Van Reenen (2001): "Skill Biased Organizational Change? Evidence from a Panel of British and French Establishments," Quarterly Journal of Economics, Vol. 116, No. 4 (November), 1449-1492.

Egger, Hartmut, and Volker Grossmann (2000): "Empowerment, Reorganization of Work, and Wage Inequality," mimeo., University of Zürich.

European Foundation for the Improvement of Living and Working Conditions (1997): New Forms of Work Organization: Can Europe Realize Its Potential?, Dublin.

European Foundation for the Improvement of Living and Working Conditions (1998): Direct Participation and Organizational Change, Dublin.

Freeman, Richard B. and Joel Rogers (1999): What Workers Want, Ithaca and London: Cornell University Press.

Gittleman, Maury, Michael Horrigan, and Mary Joyce (1998): "Flexible Workplace Practices: Evidence from a Nationally Representative Survey," Industrial and Labor Relations Review, 52(1), 99-115.

Handel, Michael, and Maury Gittleman (1999): "Is There a Wage Payoff to Innovative Work Practices?," The Jerome Levy Economics Institute Working Paper No. 288, Bard College.

Hunter, Larry W., and John J. Lafkas (1998): "Opening the Box: Information Technology, Work Practices, and Wages," Wharton School Working Paper No. 98-02-C, University of Pennsylvania.

Ichniowski, Casey, Kathryn Shaw, and Giovanna Prennushi (1997): "The Effects of Human Resource Management Practices on Productivity: A Study of Steel Finishing Lines," American Economic Review, 87(3), 291-313.

Kölling, Arnd (2000): "The IAB-Establishment Panel," Applied Social Science Studies, 120(2), 291-300.

Kremer, Michael, and Eric S. Maskin (1996): "Wage Inequality and Segregation by Skill," NBER Working Paper No. 5718, NBER, Cambridge, MA.

Kuhn, Peter and Catherine Weinberger (2001): "Leadership Skills and Wages," IZA Discussion Paper No. 482, Bonn.

Lindbeck, Assar, and Dennis J. Snower (1996): "Reorganization of Firms and Labor Market Inequality," American Economic Review, 86(2), 315-321.

Lindbeck, Assar, and D. J. Snower (2000): "Multi-Tasking and the Reorganization of Work: From Tayloristic to Holistic Organization," Journal of Labor Economics, 18(3), 353376.

Loftus, Elizabeth F., Mark R. Klinger, Kyle D. Smith, and Judith Fiedler (1990): “A Tale of Two Questions: Benefits of Asking More than One Question," Public Opinion Quarterly, Vol. 54, 330-345.

Milgrom, Paul, and John Roberts (1990): "The Economics of Modern Manufacturing: Technology, Strategy and Organization," American Economic Review, 80(3), 511-528.

Milgrom, Paul, and John Roberts (1995): "Complementarities and Fit: Strategy, Structure and Organizational Change in Manufacturing," Journal of Accounting and Economics, 19, 179-208. 
OECD (1999): Employment Outlook, Paris: OECD.

Osterman, Paul (1994): "How Common is Workplace Transformation and Who Adopts It?," Industrial and Labor Relations Review, 47(2), 173-189.

Osterman, Paul (2000): "Work Reorganization in an Era of Restructuring: Trends in Diffusion and Effects on Employee Welfare," Industrial and Labor Relations Review, 53(2), 179-196.

Snower, Dennis J. (1999): "Causes of Changing Earnings Inequality," IZA Discussion Paper No. 29, IZA, Bonn.

Sudman, Seymour, Adam Finn, and Linda Lannom (1984): "The Use of Bounded Recall Procedures in Single Interviews," Public Opinion Quarterly, Vol. 48, 520-524.

Thesmar, David, and Mathias Thoenig (2000): "Creative Destruction and Firm Organization Choice" Quarterly Journal of Economics, Vol 115, No. 4 (November), 1201-1237. 
Table 1:

Descriptive Statistics on Organizational Change in Germany

\begin{tabular}{lccc}
\hline \hline & All Firms & Manufacturing & Non-Manufacturing \\
\hline Number of Organizational Changes (in \%) & & & \\
0 & 43.07 & 33.98 & 52.28 \\
1 & 25.60 & 25.97 & 25.22 \\
2 & 18.81 & 21.24 & 16.36 \\
3 & 12.52 & 18.81 & 6.15 \\
Mean Number of Organizational Changes & 1.008 & 1.249 & 0.764 \\
& $(1.058)$ & $(1.115)$ & $(0.937)$ \\
Reduction of Hierarchy Levels (in \%) & 27.55 & 38.23 & 16.73 \\
Transfer of Responsibilities (in \%) & 42.58 & 47.21 & 37.88 \\
Introduction of Self-Managed Teams (in \%) & 30.67 & 39.44 & 21.77 \\
\hline Observations & 1,637 & 824 & 813 \\
\hline \hline
\end{tabular}

Notes: Standard deviations in parentheses. 
Table 2:

Flexible Workplace Practices and Wages, 1993-1995

\begin{tabular}{|c|c|c|c|c|}
\hline & \multicolumn{2}{|c|}{ Mean Wage } & \multicolumn{2}{|c|}{ 20\% Percentile } \\
\hline & $\begin{array}{l}1995 \\
(1)\end{array}$ & $\begin{array}{l}\text { Differenced } \\
1993-1995 \\
\text { (2) }\end{array}$ & $\begin{array}{l}1995 \\
(1)\end{array}$ & $\begin{array}{l}\text { Differenced } \\
1993-1995 \\
\text { (2) }\end{array}$ \\
\hline Reduction of Hierarchy Levels & $\begin{array}{c}0.0126^{* *} \\
(0.0062)\end{array}$ & $\begin{array}{c}0.0076^{* * *} \\
(0.0026)\end{array}$ & $\begin{array}{c}0.0164^{* *} \\
(0.0074)\end{array}$ & $\begin{array}{c}0.0075^{* *} \\
(0.0036)\end{array}$ \\
\hline Transfer of Responsibilities & $\begin{array}{c}-0.0048 \\
(0.0060)\end{array}$ & $\begin{array}{c}-0.0026 \\
(0.0022)\end{array}$ & $\begin{array}{c}-0.0039 \\
(0.0071)\end{array}$ & $\begin{array}{c}-0.0012 \\
(0.0032)\end{array}$ \\
\hline Introduction of Self-Managed Teams & $\begin{array}{c}0.0120^{* *} \\
(0.0060)\end{array}$ & $\begin{array}{c}0.0013 \\
(0.0023)\end{array}$ & $\begin{array}{c}0.0150^{* * *} \\
(0.0071)\end{array}$ & $\begin{array}{l}-0.0040 \\
(0.0031)\end{array}$ \\
\hline Investments in IT & $\begin{array}{l}0.0086 \\
(0.0077)\end{array}$ & $\begin{array}{l}0.0064^{* *} \\
(0.0031)\end{array}$ & $\begin{array}{l}0.0001 \\
(0.0091)\end{array}$ & $\begin{array}{l}0.0080^{*} \\
(0.0041)\end{array}$ \\
\hline Main Investments in IT & $\begin{array}{c}0.0080 \\
(0.0069)\end{array}$ & $\begin{array}{c}-0.0012 \\
(0.0021)\end{array}$ & $\begin{array}{c}0.0131 \\
(0.0081)\end{array}$ & $\begin{array}{c}-0.0027 \\
(0.0032)\end{array}$ \\
\hline $\log$ (Total Employment) & $\begin{array}{c}0.0280^{* * *} \\
(0.0025)\end{array}$ & $\begin{array}{c}-0.0258^{* * * *} \\
(0.0075)\end{array}$ & $\begin{array}{c}0.0264^{* * *} \\
(0.0030)\end{array}$ & $\begin{array}{c}-0.0411^{* * * *} \\
(0.0129)\end{array}$ \\
\hline Share of Unskilled Blue Collar & $\begin{array}{c}-0.5807^{* * * *} \\
(0.0390)\end{array}$ & $\begin{array}{c}-0.6013^{* * * *} \\
(0.0895)\end{array}$ & $\begin{array}{c}-0.5676^{* * * *} \\
(0.0477)\end{array}$ & $\begin{array}{c}-0.7560^{* * * *} \\
(0.1980)\end{array}$ \\
\hline Share of Skilled Blue Collar & $\begin{array}{c}-0.5772^{* * * *} \\
(0.0396)\end{array}$ & $\begin{array}{c}-0.4532^{* * * *} \\
(0.0772)\end{array}$ & $\begin{array}{c}-0.5702^{* * *} \\
(0.0482)\end{array}$ & $\begin{array}{c}-0.5275^{* * *} \\
(0.1563)\end{array}$ \\
\hline Share of High-Skilled Blue Collar & $\begin{array}{c}-0.1035^{* *} \\
(0.0417)\end{array}$ & $\begin{array}{c}-0.2740^{* * *} \\
(0.0747)\end{array}$ & $\begin{array}{c}-0.2040 * * * \\
(0.0505)\end{array}$ & $\begin{array}{c}-0.3287^{* *} \\
(0.1584)\end{array}$ \\
\hline Share of Unskilled White Collar & $\begin{array}{c}-0.5118^{* * *} \\
(0.0409)\end{array}$ & $\begin{array}{l}-0.5271 * * * \\
(0.0911)\end{array}$ & $\begin{array}{c}-0.5445^{* * *} \\
(0.0489)\end{array}$ & $\begin{array}{c}-0.6833^{* * *} \\
(0.2004)\end{array}$ \\
\hline Share of Skilled White Collar & $\begin{array}{c}-0.1705^{* * * *} \\
(0.0400)\end{array}$ & $\begin{array}{c}-0.3332^{* * *} \\
(0.0824)\end{array}$ & $\begin{array}{c}-0.2335^{* * * *} \\
(0.0511)\end{array}$ & $\begin{array}{c}-0.4438^{* * * *} \\
(0.1713)\end{array}$ \\
\hline Share of Females & $\begin{array}{c}-0.4695^{* * *} \\
(0.0256)\end{array}$ & $\begin{array}{l}-0.3085 * * * \\
(0.0427)\end{array}$ & $\begin{array}{c}-0.5616^{* * *} \\
(0.0302)\end{array}$ & $\begin{array}{c}-0.3991 * * * \\
(0.0908)\end{array}$ \\
\hline Share of Married Employees & $\begin{array}{c}0.0326 \\
(0.0215)\end{array}$ & $\begin{array}{c}0.0325^{* * * *} \\
(0.0120)\end{array}$ & $\begin{array}{c}0.0665^{* * *} \\
(0.0247)\end{array}$ & $\begin{array}{c}0.0423^{* *} \\
(0.0175)\end{array}$ \\
\hline Share of Foreigners & $\begin{array}{c}-0.1519^{* * * *} \\
(0.0346)\end{array}$ & $\begin{array}{c}-0.1090^{* * * *} \\
(0.0382)\end{array}$ & $\begin{array}{c}-0.1809^{* * * *} \\
(0.0385)\end{array}$ & $\begin{array}{l}-0.0635 \\
(0.0621)\end{array}$ \\
\hline Mean Age of Employees & $\begin{array}{c}0.5228 * * * \\
(0.0857)\end{array}$ & $\begin{array}{c}0.0006 \\
(0.0007)\end{array}$ & $\begin{array}{c}0.4498^{* * *} * \\
0.1017)\end{array}$ & $\begin{array}{c}0.0003 \\
(0.0011)\end{array}$ \\
\hline Export Share & $\begin{array}{l}0.0250^{*} \\
(0.0128)\end{array}$ & $\begin{array}{c}0.0192^{* * * *} \\
(0.0073)\end{array}$ & $\begin{array}{c}0.0109 \\
(0.0156)\end{array}$ & $\begin{array}{l}0.0162^{*} \\
(0.0095)\end{array}$ \\
\hline State-of-the-art Technology & $\begin{array}{c}0.0080 \\
(0.0059)\end{array}$ & $\begin{array}{c}0.0033^{*} \\
(0.0019)\end{array}$ & $\begin{array}{c}0.0072 \\
(0.0070)\end{array}$ & $\begin{array}{c}0.0056^{* *} \\
(0.0027)\end{array}$ \\
\hline Single Firm & $\begin{array}{c}-0.0196^{* * *} \\
(0.0062)\end{array}$ & $\begin{array}{c}0.0005 \\
(0.0017)\end{array}$ & $\begin{array}{c}-0.0265^{* * *} \\
(0.0072)\end{array}$ & $\begin{array}{c}-0.0018 \\
(0.0026)\end{array}$ \\
\hline Works Council & $\begin{array}{c}0.0225^{* * *} \\
(0.0072)\end{array}$ & $\begin{array}{c}-0.0004 \\
(0.0027)\end{array}$ & $\begin{array}{c}0.0253^{* * *} \\
(0.0085)\end{array}$ & $\begin{array}{l}-0.0004 \\
(0.0039)\end{array}$ \\
\hline Revenues increased $_{t-1}$ & $\begin{array}{c}-0.0018 \\
(0.0066)\end{array}$ & $\begin{array}{c}0.0023 \\
(0.0018)\end{array}$ & $\begin{array}{c}-0.0099 \\
(0.0078)\end{array}$ & $\begin{array}{l}-0.0007 \\
(0.0025)\end{array}$ \\
\hline Revenues decreased $_{t-1}$ & $\begin{array}{c}-0.0093 \\
(0.0077)\end{array}$ & $\begin{array}{c}-0.0053^{*} \\
(0.0027)\end{array}$ & $\begin{array}{c}-0.0190^{* * *} \\
(0.0090)\end{array}$ & $\begin{array}{c}-0.0085^{* *} \\
(0.0036)\end{array}$ \\
\hline Constant & $\begin{array}{c}5.2561^{* * * *} \\
(0.0544)\end{array}$ & $\begin{array}{c}0.0108^{* * * *} \\
(0.0032)\end{array}$ & $\begin{array}{c}5.1439^{* * * *} \\
(0.0654)\end{array}$ & $\begin{array}{c}0.0097^{* * *} \\
(0.0044)\end{array}$ \\
\hline R-squared & 0.71 & 0.32 & 0.66 & 0.27 \\
\hline
\end{tabular}


Table 2 continued:

Flexible Workplace Practices and Wages, 1993-1995

\begin{tabular}{|c|c|c|c|c|}
\hline & \multicolumn{2}{|c|}{$50 \%$ Percentile } & \multicolumn{2}{|c|}{$80 \%$ Percentile } \\
\hline & $\begin{array}{l}1995 \\
(1)\end{array}$ & $\begin{array}{c}\text { Differenced } \\
1993-1995 \\
\text { (2) }\end{array}$ & $\begin{array}{l}1995 \\
(1)\end{array}$ & $\begin{array}{c}\text { Differenced } \\
1993-1995 \\
\text { (2) }\end{array}$ \\
\hline Reduction of Hierarchy Levels & $\begin{array}{c}0.0133^{*} \\
(0.0070)\end{array}$ & $\begin{array}{c}0.0104^{* * *} \\
(0.0028)\end{array}$ & $\begin{array}{c}0.0110 \\
(0.0068)\end{array}$ & $\begin{array}{c}0.0057^{* *} \\
(0.0027)\end{array}$ \\
\hline Transfer of Responsibilities & $\begin{array}{l}-0.0043 \\
(0.0066)\end{array}$ & $\begin{array}{c}-0.0054^{* *} \\
(0.0026)\end{array}$ & $\begin{array}{l}-0.0043 \\
(0.0063)\end{array}$ & $\begin{array}{l}-0.0001 \\
(0.0025)\end{array}$ \\
\hline Introduction of Self-Managed Teams & $\begin{array}{l}0.0119^{*} \\
(0.0067)\end{array}$ & $\begin{array}{c}0.0034 \\
(0.0027)\end{array}$ & $\begin{array}{c}0.0051 \\
(0.0066)\end{array}$ & $\begin{array}{c}0.0029 \\
(0.0025)\end{array}$ \\
\hline Investments in IT & $\begin{array}{c}0.0075 \\
(0.0085)\end{array}$ & $\begin{array}{c}0.0038 \\
(0.0035)\end{array}$ & $\begin{array}{c}0.0215^{* * * *} \\
(0.0081)\end{array}$ & $\begin{array}{c}0.0032 \\
(0.0033)\end{array}$ \\
\hline Main Investments in IT & $\begin{array}{c}0.0096 \\
(0.0076)\end{array}$ & $\begin{array}{c}0.0010 \\
(0.0025)\end{array}$ & $\begin{array}{c}0.0009 \\
(0.0076)\end{array}$ & $\begin{array}{c}0.0001 \\
(0.0025)\end{array}$ \\
\hline $\log$ (Total Employment) & $\begin{array}{c}0.0260^{* * *} \\
(0.0028)\end{array}$ & $\begin{array}{c}-0.0228^{* * * *} \\
(0.0078)\end{array}$ & $\begin{array}{c}0.0290 * * * \\
(0.0027)\end{array}$ & $\begin{array}{c}-0.0116^{*} \\
(0.0069)\end{array}$ \\
\hline Share of Unskilled Blue Collar & $\begin{array}{c}-0.6788^{* * *} * \\
(0.0415)\end{array}$ & $\begin{array}{c}-0.5967^{* * *} \\
(0.0756)\end{array}$ & $\begin{array}{c}-0.6346^{* * *} \\
(0.0397)\end{array}$ & $\begin{array}{c}-0.5033^{* * *} * \\
(0.0541)\end{array}$ \\
\hline Share of Skilled Blue Collar & $\begin{array}{c}-0.6444^{* * *} \\
(0.0428)\end{array}$ & $\begin{array}{c}-0.4575^{* * *} \\
(0.0732)\end{array}$ & $\begin{array}{c}-0.6102^{* * *} \\
(0.0412)\end{array}$ & $\begin{array}{c}-0.3878^{* * * *} \\
(0.0608)\end{array}$ \\
\hline Share of High-Skilled Blue Collar & $\begin{array}{c}-0.1341^{* * *} \\
(0.0445)\end{array}$ & $\begin{array}{c}-0.2710^{* * * *} \\
(0.0684)\end{array}$ & $\begin{array}{c}0.0006 \\
(0.0443)\end{array}$ & $\begin{array}{c}-0.2133^{* * *} * \\
(0.0477)\end{array}$ \\
\hline Share of Unskilled White Collar & $\begin{array}{c}-0.5834^{* * *} \\
(0.0453)\end{array}$ & $\begin{array}{c}-0.5471^{* * *} \\
(0.0745)\end{array}$ & $\begin{array}{c}-0.5009 * * * \\
(0.0427)\end{array}$ & $\begin{array}{c}-0.3698^{* * *} * \\
(0.0579)\end{array}$ \\
\hline Share of Skilled White Collar & $\begin{array}{c}-0.2061^{* * *} * \\
(0.0428)\end{array}$ & $\begin{array}{c}-0.2902^{* * * *} \\
(0.0695)\end{array}$ & $\begin{array}{c}-0.1108^{* * *} * \\
(0.0409)\end{array}$ & $\begin{array}{c}-0.1808^{* * *} \\
(0.0517)\end{array}$ \\
\hline Share of Females & $\begin{array}{c}-0.5179 * * * \\
(0.0277)\end{array}$ & $\begin{array}{c}-0.2436^{* * *} \\
(0.0390)\end{array}$ & $\begin{array}{c}-0.3840^{* * *} \\
(0.0267)\end{array}$ & $\begin{array}{c}-0.2133^{* * *} * \\
(0.0486)\end{array}$ \\
\hline Share of Married Employees & $\begin{array}{c}0.0344 \\
(0.0238)\end{array}$ & $\begin{array}{c}0.0389 * * * \\
(0.0135)\end{array}$ & $\begin{array}{c}0.0025 \\
(0.0236)\end{array}$ & $\begin{array}{c}0.0184 \\
(0.0153)\end{array}$ \\
\hline Share of Foreigners & $\begin{array}{c}-0.1885^{* * *} \\
(0.0378)\end{array}$ & $\begin{array}{l}-0.0795^{*} \\
(0.0436)\end{array}$ & $\begin{array}{c}-0.0971^{* * *} \\
(0.0361)\end{array}$ & $\begin{array}{c}-0.0979^{*} * \\
(0.0475)\end{array}$ \\
\hline Mean Age of Employees & $\begin{array}{c}0.5982^{* * *} \\
(0.0953)\end{array}$ & $\begin{array}{c}0.0004 \\
(0.0008)\end{array}$ & $\begin{array}{c}0.5873^{* * *} \\
(0.0868)\end{array}$ & $\begin{array}{c}0.0012 \\
(0.0008)\end{array}$ \\
\hline Export Share & $\begin{array}{c}0.0218 \\
(0.0143)\end{array}$ & $\begin{array}{c}0.0193^{* *} \\
(0.0092)\end{array}$ & $\begin{array}{c}0.0457^{* * *} * \\
(0.0138)\end{array}$ & $\begin{array}{c}0.0259 * * * \\
(0.0097)\end{array}$ \\
\hline State-of-the-art Technology & $\begin{array}{l}0.0110^{*} \\
(0.0065)\end{array}$ & $\begin{array}{c}0.0038 \\
(0.0023)\end{array}$ & $\begin{array}{c}0.0085 \\
(0.0062)\end{array}$ & $\begin{array}{c}0.0004 \\
(0.0022)\end{array}$ \\
\hline Single Firm & $\begin{array}{c}-0.0188^{* * * *} \\
(0.0068)\end{array}$ & $\begin{array}{c}0.0010 \\
(0.0021)\end{array}$ & $\begin{array}{l}-0.0103 \\
(0.0066)\end{array}$ & $\begin{array}{c}0.0017 \\
(0.0021)\end{array}$ \\
\hline Works Council & $\begin{array}{c}0.0171^{* * *} \\
(0.0080)\end{array}$ & $\begin{array}{l}-0.0022 \\
(0.0032)\end{array}$ & $\begin{array}{l}0.0152^{* *} \\
(0.0077)\end{array}$ & $\begin{array}{c}0.0010 \\
(0.0033)\end{array}$ \\
\hline Revenues increased $_{t-1}$ & $\begin{array}{l}-0.0038 \\
(0.0073)\end{array}$ & $\begin{array}{c}0.0046^{* *} \\
(0.0022)\end{array}$ & $\begin{array}{c}0.0046 \\
(0.0070)\end{array}$ & $\begin{array}{c}0.0048^{* *} \\
(0.0021)\end{array}$ \\
\hline Revenues decreased $_{t-1}$ & $\begin{array}{l}-0.0135 \\
(0.0086)\end{array}$ & $\begin{array}{c}-0.0061^{* * *} \\
(0.0030)\end{array}$ & $\begin{array}{l}-0.0047 \\
(0.0086)\end{array}$ & $\begin{array}{l}-0.0031 \\
(0.0031)\end{array}$ \\
\hline Constant & $\begin{array}{c}5.3041^{* * * *} \\
(0.0594)\end{array}$ & $\begin{array}{c}0.0115^{* * *} \\
(0.0035)\end{array}$ & $\begin{array}{c}5.4007^{* * *} * \\
(0.0579)\end{array}$ & $\begin{array}{c}0.0131^{* * *} * \\
(0.0033)\end{array}$ \\
\hline R-squared & 0.71 & 0.25 & 0.69 & 0.19 \\
\hline
\end{tabular}

Notes: Robust standard errors in parentheses. 1,637 observations. The cross-sectional estimates also include 7 industry dummies and 9 regional dummies. $* * *$ : statistically significant at least at the 1\%-level. $* *$ :statistically significant at least at the 5\%-level. $*$ :statistically significant at least at the $10 \%$-level. 
Table 3:

Flexible Workplace Practices and Wages: Alternative Specifications, 1993-1995

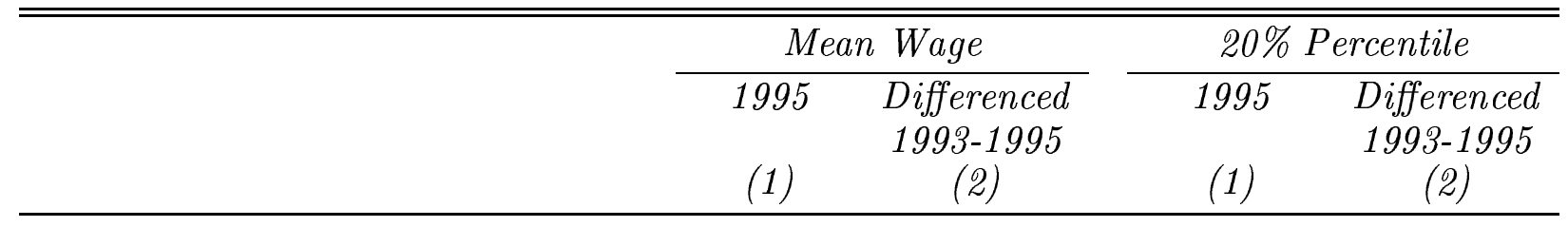

Panel A: Coefficients on Single Work Practices

Reduction of Hierarchy Levels

$\begin{array}{llll}0.0134^{* *} & 0.0068^{* * *} & 0.0182^{* * *} & 0.0059^{*} \\ (0.0057) & (0.0024) & (0.0068) & (0.0034) \\ 0.0025 & 0.0004 & 0.0054 & 0.0001 \\ (0.0054) & (0.0020) & (0.0064) & (0.0029) \\ 0.0129^{* *} & 0.0023 & 0.0170^{* *} & -0.0025 \\ (0.0058) & (0.0020) & (0.0068) & (0.0029)\end{array}$

Panel B: Index of HPWO

Index of HPWO

$$
\begin{array}{llll}
0.0060^{* *} & 0.0019^{*} & 0.0086^{* * *} & 0.0006 \\
(0.0028) & (0.0010) & (0.0032) & (0.0014)
\end{array}
$$

\begin{tabular}{|c|c|c|c|c|}
\hline & \multicolumn{2}{|c|}{$50 \%$ Percentile } & \multicolumn{2}{|c|}{$80 \%$ Percentile } \\
\hline & $\begin{array}{c}1995 \\
(1)\end{array}$ & $\begin{array}{c}\text { Differenced } \\
1993-1995 \\
\text { (2) }\end{array}$ & $\begin{array}{c}1995 \\
(1)\end{array}$ & $\begin{array}{c}\text { Differenced } \\
1993-1995 \\
\text { (2) }\end{array}$ \\
\hline \multicolumn{5}{|c|}{ Panel A: Coefficients on Single Work Practices } \\
\hline Reduction of Hierarchy Levels & $\begin{array}{l}0.0143^{* *} \\
(0.0064)\end{array}$ & $\begin{array}{l}0.0090^{* * *} \\
(0.0026)\end{array}$ & $\begin{array}{l}0.0103^{*} \\
(0.0062)\end{array}$ & $\begin{array}{l}0.0065^{* *} \\
(0.0026)\end{array}$ \\
\hline Transfer of Responsibilities & $\begin{array}{l}0.0032 \\
(0.0060)\end{array}$ & $\begin{array}{l}-0.0008 \\
(0.0023)\end{array}$ & $\begin{array}{l}0.0005 \\
(0.0058)\end{array}$ & $\begin{array}{l}0.0028 \\
(0.0023)\end{array}$ \\
\hline Introduction of Self-Managed Teams & $\begin{array}{l}0.0130^{* *} \\
(0.0064)\end{array}$ & $\begin{array}{l}0.0040^{*} \\
(0.0024)\end{array}$ & $\begin{array}{l}0.0058 \\
(0.0064)\end{array}$ & $\begin{array}{l}0.0044^{* *} \\
(0.0022)\end{array}$ \\
\hline \multicolumn{5}{|l|}{ Panel B: Index of HPWO } \\
\hline Index of HPWO & $\begin{array}{l}0.0064^{* *} \\
(0.0031)\end{array}$ & $\begin{array}{l}0.0023^{* *} \\
(0.0011)\end{array}$ & $\begin{array}{l}0.0034 \\
(0.0030)\end{array}$ & $\begin{array}{l}0.0028^{* *} \\
(0.0011)\end{array}$ \\
\hline
\end{tabular}

Notes: 1,637 observations. All equations include the same variables as in Table 2. See also notes to Table 2 . 


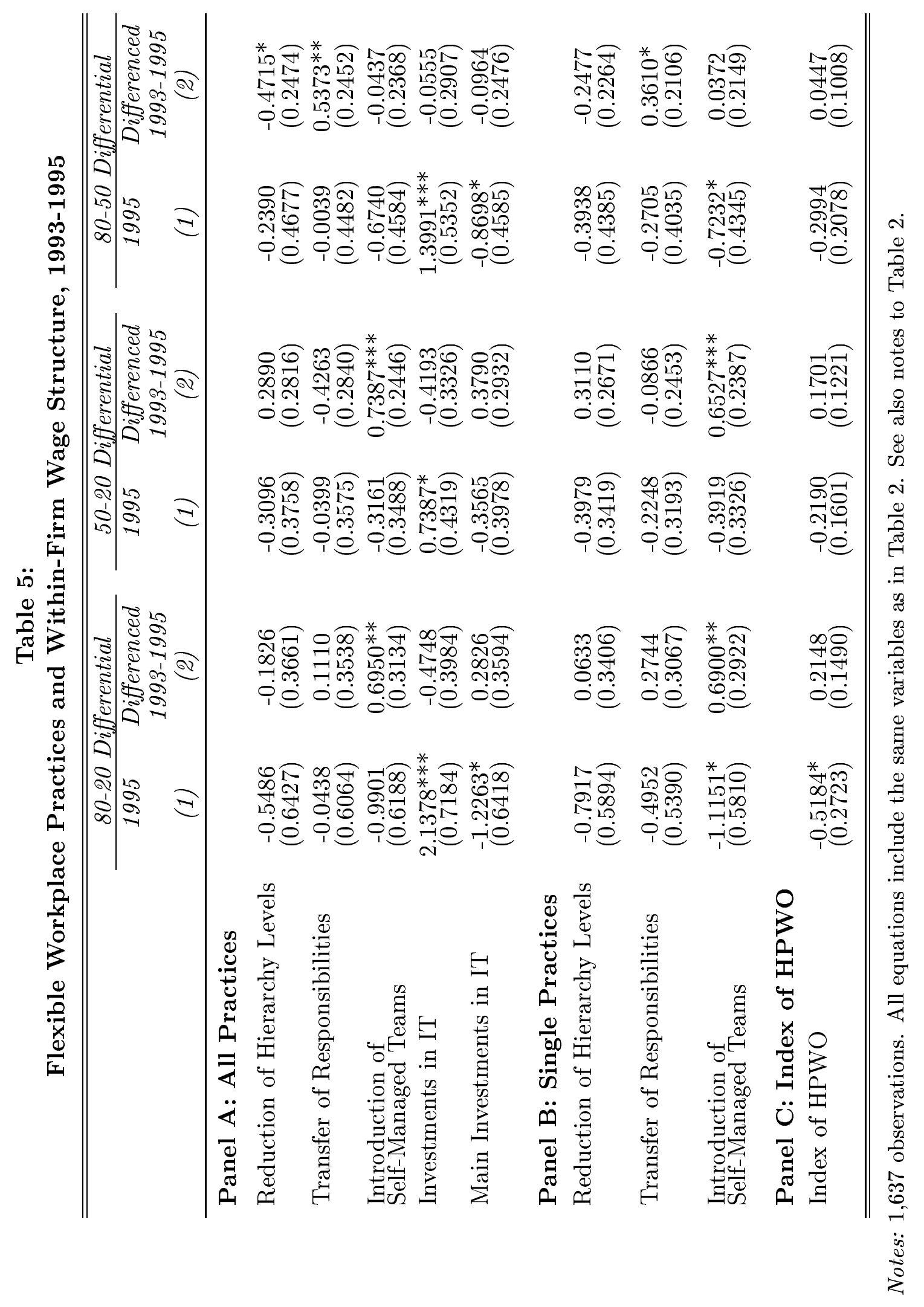




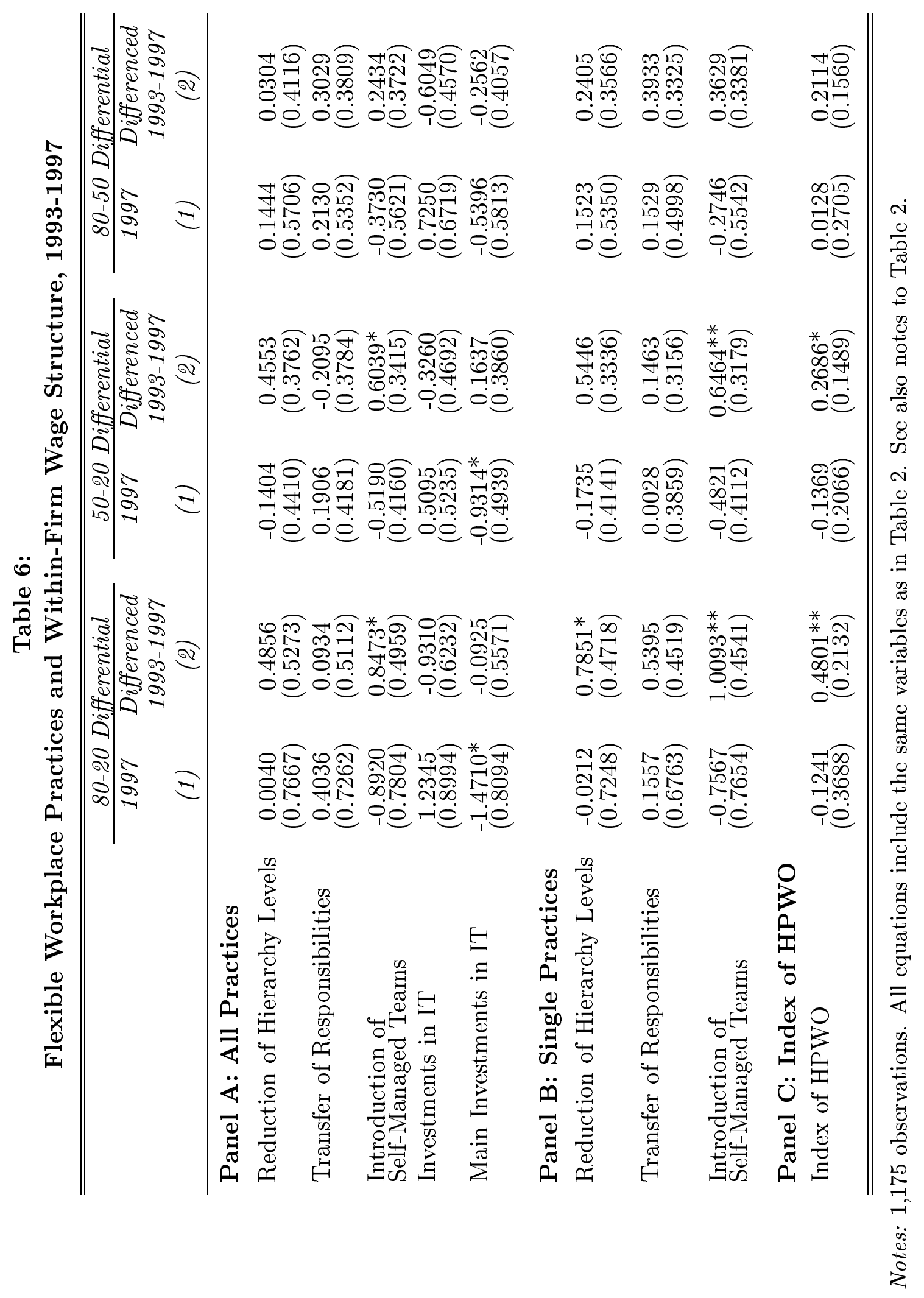




\section{Appendix-Table 1:}

Variable Description and Descriptive Statistics

\begin{tabular}{|c|c|c|c|c|}
\hline Variable & Definition & 1997 & 1995 & 1993 \\
\hline Mean Wage & $\begin{array}{l}\text { Logarithm of the real daily establishment } \\
\text { mean wage. } \\
\text { From Employment Statistics Register. }\end{array}$ & $\begin{array}{c}5.064 \\
(0.193)\end{array}$ & $\begin{array}{c}5.057 \\
(0.192)\end{array}$ & $\begin{array}{c}5.045 \\
(0.188)\end{array}$ \\
\hline Wage at $20 \%$ Percentile & $\begin{array}{l}\text { Logarithm of the real daily establishment } \\
\text { wage at the } 20 \% \text {-percentile. } \\
\text { From Employment Statistics Register. }\end{array}$ & $\begin{array}{c}4.881 \\
(0.209)\end{array}$ & $\begin{array}{c}4.866 \\
(0.210)\end{array}$ & $\begin{array}{c}4.854 \\
(0.208)\end{array}$ \\
\hline Wage at $50 \%$ Percentile & $\begin{array}{l}\text { Logarithm of the real daily establishment } \\
\text { wage at the } 50 \% \text {-percentile. } \\
\text { From Employment Statistics Register. }\end{array}$ & $\begin{array}{c}5.050 \\
(0.212)\end{array}$ & $\begin{array}{l}5.043 \\
(0.210)\end{array}$ & $\begin{array}{c}5.031 \\
(0.206)\end{array}$ \\
\hline Wage at $80 \%$ Percentile & $\begin{array}{l}\text { Logarithm of the real daily establishment } \\
\text { wage at the } 80 \% \text {-percentile. } \\
\text { From Employment Statistics Register. }\end{array}$ & $\begin{array}{c}5.260 \\
(0.204)\end{array}$ & $\begin{array}{c}5.259 \\
(0.198)\end{array}$ & $\begin{array}{l}5.247 \\
(0.195)\end{array}$ \\
\hline 80-20 Wage Differential & $\begin{array}{l}\text { Difference between the wage at the } \\
80 \% \text { and } 20 \% \text { percentile in } \% \text {. } \\
\text { From Employment Statistics Register. }\end{array}$ & $\begin{array}{l}37.843 \\
(12.763)\end{array}$ & $\begin{array}{c}39.290 \\
(12.349)\end{array}$ & $\begin{array}{c}39.315 \\
(12.547)\end{array}$ \\
\hline 50-20 Wage Differential & $\begin{array}{l}\text { Difference between the wage at the } \\
50 \% \text { and } 20 \% \text { percentile in } \% \text {. } \\
\text { From Employment Statistics Register. }\end{array}$ & $\begin{array}{c}16.929 \\
(7.488)\end{array}$ & $\begin{array}{l}17.649 \\
(7.490)\end{array}$ & $\begin{array}{c}17.722 \\
(7.836)\end{array}$ \\
\hline 80-50 Wage Differential & $\begin{array}{l}\text { Difference between the wage at the } \\
80 \% \text { and } 50 \% \text { percentile in \%. } \\
\text { From Employment Statistics Register. }\end{array}$ & $\begin{array}{l}20.914 \\
(8.694)\end{array}$ & $\begin{array}{l}21.641 \\
(8.487)\end{array}$ & $\begin{array}{c}21.593 \\
(8.509)\end{array}$ \\
\hline $\log$ (Total Employment) & $\begin{array}{l}\text { Logarithm of total number of employees } \\
\text { paying social security contributions. } \\
\text { From Employment Statistics Register. }\end{array}$ & $\begin{array}{c}5.572 \\
(1.418)\end{array}$ & $\begin{array}{c}5.587 \\
(1.435)\end{array}$ & $\begin{array}{c}5.613 \\
(1.480)\end{array}$ \\
\hline Unskilled Blue Collar & $\begin{array}{l}\text { Percentage of unskilled blue-collar } \\
\text { workers. } \\
\text { From Employment Statistics Register. }\end{array}$ & $\begin{array}{c}0.223 \\
(0.253)\end{array}$ & $\begin{array}{c}0.219 \\
(0.251)\end{array}$ & $\begin{array}{c}0.222 \\
(0.252)\end{array}$ \\
\hline Skilled Blue Collar & $\begin{array}{l}\text { Percentage of skilled blue-collar } \\
\text { workers. } \\
\text { From Employment Statistics Register. }\end{array}$ & $\begin{array}{c}0.163 \\
(0.181)\end{array}$ & $\begin{array}{c}0.168 \\
(0.189)\end{array}$ & $\begin{array}{c}0.170 \\
(0.191)\end{array}$ \\
\hline High-Skilled Blue Collar & $\begin{array}{l}\text { Percentage of high-skilled blue-collar } \\
\text { workers. } \\
\text { From Employment Statistics Register. }\end{array}$ & $\begin{array}{c}0.103 \\
(0.133)\end{array}$ & $\begin{array}{c}0.102 \\
(0.133)\end{array}$ & $\begin{array}{c}0.097 \\
(0.127)\end{array}$ \\
\hline Unskilled White Collar & $\begin{array}{l}\text { Percentage of unskilled white-collar } \\
\text { workers. } \\
\text { From Employment Statistics Register. }\end{array}$ & $\begin{array}{c}0.166 \\
(0.207)\end{array}$ & $\begin{array}{c}0.170 \\
(0.207)\end{array}$ & $\begin{array}{c}0.175 \\
(0.208)\end{array}$ \\
\hline Skilled White Collar & $\begin{array}{l}\text { Percentage of skilled white-collar } \\
\text { workers. } \\
\text { From Employment Statistics Register. }\end{array}$ & $\begin{array}{c}0.247 \\
(0.265)\end{array}$ & $\begin{array}{c}0.238 \\
(0.257)\end{array}$ & $\begin{array}{c}0.235 \\
(0.254)\end{array}$ \\
\hline Share of Females & $\begin{array}{l}\text { Women as percentage of all employees. } \\
\text { From Employment Statistics Register. }\end{array}$ & $\begin{array}{c}0.310 \\
(0.237)\end{array}$ & $\begin{array}{c}0.313 \\
(0.233)\end{array}$ & $\begin{array}{c}0.321 \\
(0.236)\end{array}$ \\
\hline Share of Married Employees & $\begin{array}{l}\text { Married as percentage of all employees. } \\
\text { From Employment Statistics Register. }\end{array}$ & $\begin{array}{c}0.588 \\
(0.149)\end{array}$ & $\begin{array}{c}0.574 \\
(0.160)\end{array}$ & $\begin{array}{c}0.567 \\
(0.168)\end{array}$ \\
\hline Share of Foreigners & $\begin{array}{l}\text { Foreigners as percentage of all employees. } \\
\text { From Employment Statistics Register. }\end{array}$ & $\begin{array}{c}0.094 \\
(0.104)\end{array}$ & $\begin{array}{c}0.101 \\
(0.115)\end{array}$ & $\begin{array}{c}0.101 \\
(0.115)\end{array}$ \\
\hline Mean Age of Employees & $\begin{array}{l}\text { Mean age of employees } \\
\text { From Employment Statistics Register. }\end{array}$ & $\begin{array}{l}39.493 \\
(3.935)\end{array}$ & $\begin{array}{l}38.685 \\
(4.259)\end{array}$ & $\begin{array}{l}38.084 \\
(4.468)\end{array}$ \\
\hline Export Share & $\begin{array}{l}\text { Percentage Share of exports on total revenues } \\
\text { in the last year. } \\
\text { From IAB Employer Survey. }\end{array}$ & $\begin{array}{c}0.164 \\
(0.239)\end{array}$ & $\begin{array}{c}0.136 \\
(0.220)\end{array}$ & $\begin{array}{c}0.105 \\
(0.197)\end{array}$ \\
\hline State-of-the-art Technology & $\begin{array}{l}1 \text { if establishment uses state-of-the-art } \\
\text { technology relative to other establishments } \\
\text { in the industry, } 0 \text { otherwise. } \\
\text { From IAB Employer Survey. }\end{array}$ & $\begin{array}{c}0.718 \\
(0.450)\end{array}$ & $\begin{array}{c}0.706 \\
(0.456)\end{array}$ & $\begin{array}{c}0.792 \\
(0.406)\end{array}$ \\
\hline Single Firm & $\begin{array}{l}1 \text { if single firm, } 0 \text { otherwise. } \\
\text { From IAB Employer Survey. }\end{array}$ & $\begin{array}{c}0.452 \\
(0.498)\end{array}$ & $\begin{array}{c}0.392 \\
(0.488)\end{array}$ & $\begin{array}{c}0.456 \\
(0.498)\end{array}$ \\
\hline Works Council & $\begin{array}{l}1 \text { if works council is present, } 0 \text { otherwise. } \\
\text { From IAB Employer Survey. }\end{array}$ & $\begin{array}{c}0.815 \\
(0.388)\end{array}$ & $\begin{array}{c}0.717 \\
(0.451)\end{array}$ & $\begin{array}{c}0.842 \\
(0.365)\end{array}$ \\
\hline Revenues increased in-1 $_{1}$ & $\begin{array}{l}1 \text { if revenues of establishment increased last year, } \\
0 \text { otherwise. } \\
\text { From IAB Employer Survey. }\end{array}$ & $\begin{array}{c}0.432 \\
(0.496)\end{array}$ & $\begin{array}{c}0.514 \\
(0.500)\end{array}$ & $\begin{array}{c}0.566 \\
(0.496)\end{array}$ \\
\hline Revenues decreased $t_{t-1}$ & $\begin{array}{l}1 \text { if revenues of establishment decreased last year, } \\
0 \text { otherwise. } \\
\text { From IAB Employer Survey. }\end{array}$ & $\begin{array}{c}0.300 \\
(0.459)\end{array}$ & $\begin{array}{c}0.206 \\
(0.404)\end{array}$ & $\begin{array}{c}0.204 \\
(0.403)\end{array}$ \\
\hline
\end{tabular}

Notes: 1,637 Observations. 


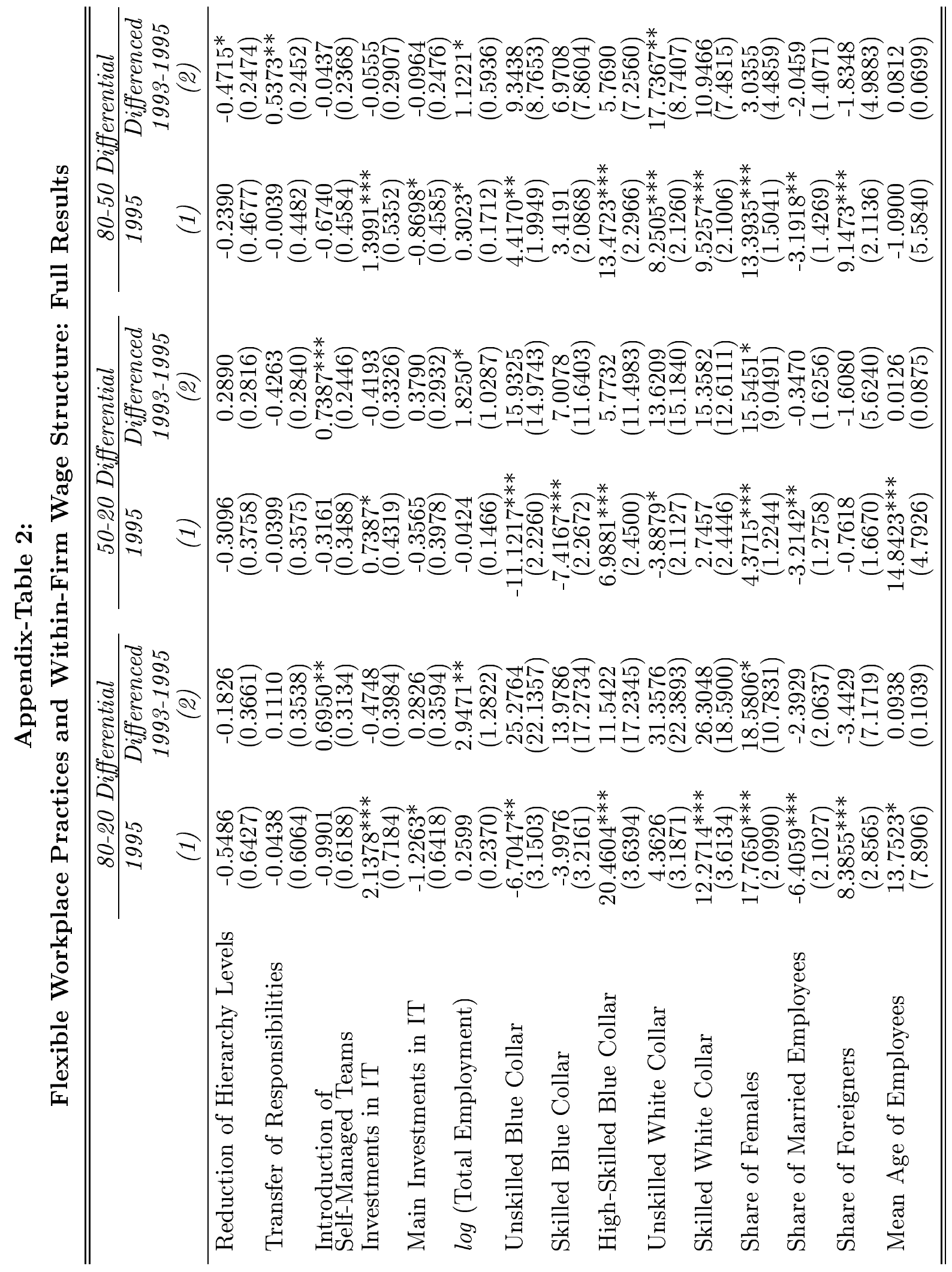




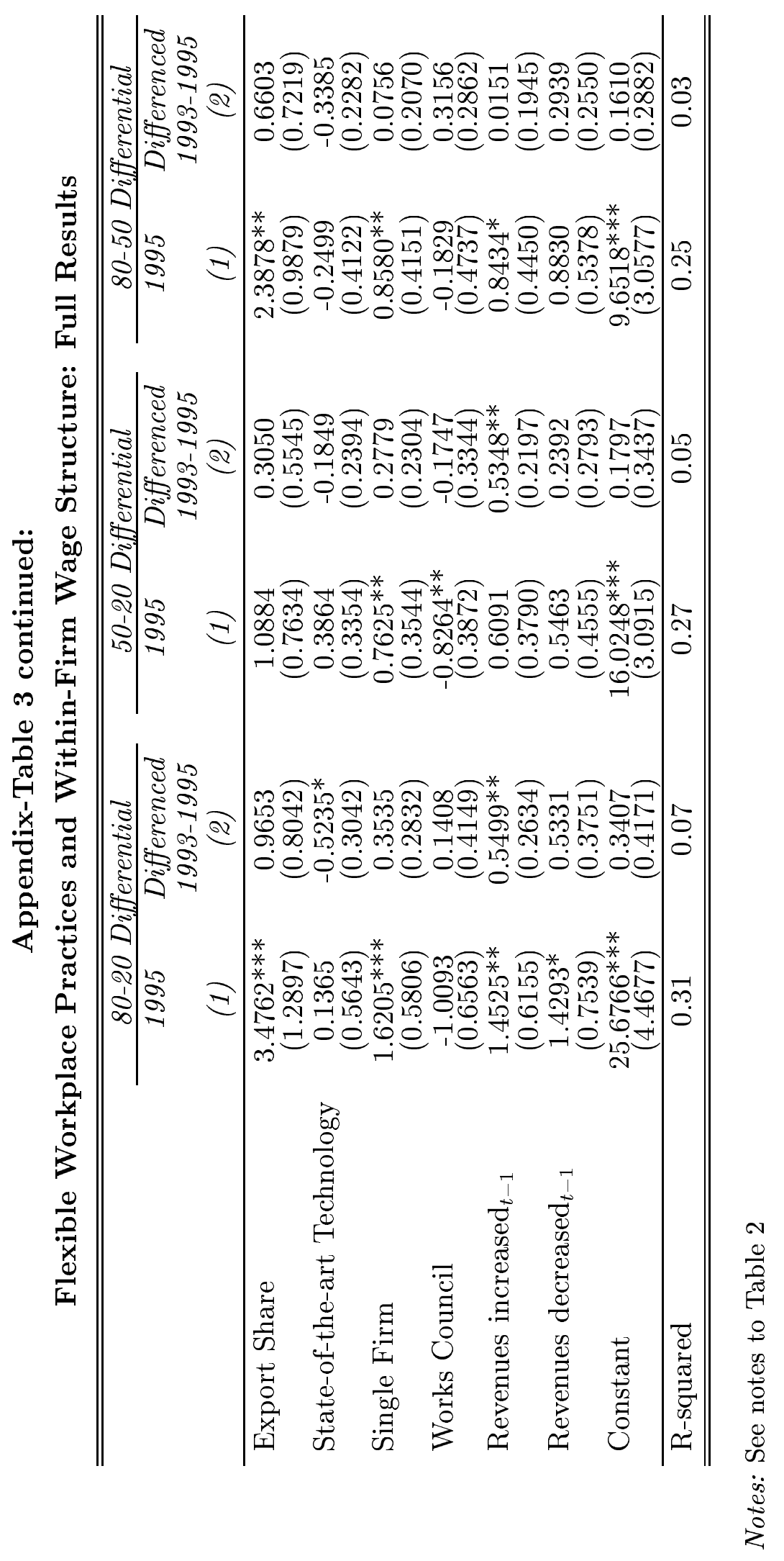




\section{IZA Discussion Papers}

No. Author(s)

280

P. Apps

R. Rees

281

G. Saint-Paul

282

J. Albrecht

A. Björklund

S. Vroman

283

M. Hagedorn

A. Kaul

V. Reinthaler

284

H. Rapoport

A. Weiss

285

J. Jerger

C. Pohnke

A. Spermann

286

M. Fertig

C. M. Schmidt

287

P. Guggenberger

A. Kaul

M. Kolmar

288

D. A. Cobb-Clark

289

L. Cameron

D. A. Cobb-Clark
D. A. Cobb-Clark

M. D. Connolly

C. Worswick
Title

Area

Date

Household Saving and Full Consumption over

7

04/01

the Life Cycle

Information Technology and the Knowledge

5

$04 / 01$

Elites

Is There a Glass Ceiling in Sweden?

5

$04 / 01$

Welfare Analysis in a Schumpeterian Growth

7

$04 / 01$

Model with Capital

The Optimal Size for a Minority

1

$04 / 01$

Gut betreut in den Arbeitsmarkt?

5

$04 / 01$

Eine mikroökonometrische Evaluation der

Mannheimer Arbeitsvermittlungsagentur

First- and Second-Generation Migrants in

1

04/01

Germany - What Do We Know and What Do

People Think

Efficiency Properties of Labor Taxation in a

3

04/01

Spatial Model of Restricted Labor Mobility

Getting Ahead: The Determinants of and Payoffs 5

$04 / 01$ to Internal Promotion for Young U.S. Men and Women

Old-Age Support in Developing Countries: Labor Supply, Intergenerational Transfers and Living Arrangements

3

04/01

The Job Search and Education Investments of

$04 / 01$ Immigrant Families

Cohort Effects in the Educational Attainment of

05/01

Second Generation Immigrants in Germany:

An Analysis of Census Data 

and the Rising Returns to Skill: US and France 1964-2000

N. Smith

L. Husted
A. Stutzer
R. Lalive

301

J. R. Frick

G. G. Wagner firm Bargaining 

H. Bonin
G. Abío
E. Berenguer
J. Gil
C. Patxot

307

G. A. Pfann

308

G. A. Pfann

D. S. Hamermesh

309

G. Brunello

310

U. Sunde

311

G. Brunello

312

C. Furnée

M. Kemler

G. A. Pfann

313
A. Ferrer-i-Carbonell
B. M.S. van Praag

314

B. M.S. van Praag

A. Ferrer-i-Carbonell

315

316

R. Winkelmann

M. Pannenberg

G. G. Wagner

319

R. Euwals

R. Winkelmann
Is the Deficit under Control? A Generational

2

06/01

Accounting Perspective on Fiscal Policy and

Labour Market Trends in Spain 

A. Frederiksen
E. K. Graversen
N. Smith Wages 2000 
